

\title{
A New Alliance Axis in the Eastern Mediterranean Cold War: What the Abraham Accords Mean for Mediterranean Geopolitics and Turkey
}

\author{
NURŞIN ATEŞOĞLU GÜNEY* and ViŞNE KORKMAZ ${ }^{* *}$ \\ * Nişantaşı University, Turkey \\ ORCID No: 0000-0002-4974-3986 \\ ** Nişantaşı University, Turkey \\ ORCID No: 0000-0001-5590-8604
}

aвstract The new Cold War has arrived in the Eastern Mediterranean. At the strategic level, Chinese economic and Russian military assertiveness have led the U.S. to think twice about its mistakes, which opened up a power vacuum in this strategic geopolitical realm. Until today, the U.S. has seemed to use three axes of alliances that have emerged as Israeli-based, flexible, and benefit-oriented alignments at the level of regional rivalry. These alignments, especially in the context of the Abraham Accords, are unfortunately expected to reinforce pre-existing divisions in the region unless a radical change occurs. This study examines how and why Washington must embrace the logic of alliance axes to shape the Eastern Mediterranean and explores the projected impact of the U.S.-initiated Abraham Accords on regional geopolitics.

Keywords: Geopolitics, U.S., Axes of Alliances, Abraham Accords, Eastern Mediterranean

Insight Turkey 2021

Vol. 23 / No. 1 / pp. 61-76

Received Date: 20/12/2020 • Accepted Date: 18/02/2021 • DOI: 10.25253/99.2021231.6 


\section{Introduction}

$\mathrm{n}$ this paper, we assume that the new Cold War, a new kind of great power rivalry, has arrived in the Eastern Mediterranean since 2015. At the strategic level, Chinese economic and Russian military assertiveness have led the U.S. to think twice about its mistakes, which opened up a power vacuum in this strategic geopolitical realm. Washington must find cost-free instruments with which to reshape the structural and institutional design of Eastern Mediterranean geopolitics, which are fragmented and confrontational at the regional level because of the severe, ongoing power struggle. We also assume that as a cost-free instrument the U.S. has decided to use already existing alliance axes in the region. The first and second axes are the direct result of a geopolitical power struggle for benefit among the regional players. The first axis emerged within energy competition in the Eastern Mediterranean and it was the direct result of strategic cooperation between Israel, Greece, South Cyprus, and Egypt -evolved and quickly militarized after 2013. The second axis emerged from the turmoil in Libya. It was crystallized after 2015 when Russia, France, UAE, and Israel decided to back Khalifa Haftar. These two axes have gradually gained an anti-Turkish stand due to Turkey's game-changing role both in terms of the energy issue and the Libyan war. However, the U.S. decision to support these axes is related to Washington's aspiration to contain Russian and Chinese influence in the region. For this aim, the U.S. initiated a third axis of alliance by negotiating the Abraham Accords with Israel, the UAE, Bahrain, Sudan, and Morocco in 2020.

In this regard first, we will try to explain what kind of great power rivalry has been observed in the Eastern Mediterranean by underlining new alliance logic of the new great power struggle between the U.S., Russia, and China. After this brief theoretical framework, we will try to answer the question of how the U.S. has caught the opportunity of using the alignment frameworks in the region. These alignments seem to the U.S. as suitable instruments because they are already emerged, militarized, and targeting other regional states, like Turkey rather than directly provoking Russia and /or China. Then, we will try to explain why the U.S. needs the third axis of alignments by negotiating the Abraham Accords between Israel and the four Arab states. Lastly, we will explore what will be the likely impacts of the Abraham Accords on the regional balance of power.

\section{Regional Alliance Patterns of the New Great Power Rivalry}

International Relations (IR) academics have often revisited the old concepts of international politics during the last decade to explain what happened after the demise of 'New World Order' dreams. One of these concepts is the Cold War. 
Some argue that we are witnessing the rise of a new Cold War era; in other words, the return of great power competition between the U.S., Russia, and China. Without a doubt, this new Cold War is not the same as the Cold War of 1947-1991 when the world was divided between ideologically enemy camps.

\section{The major likeness between the old and the new Cold War is the main geopolitical consequence of the great power rivalry: emergence of spheres of influence}

However, we also witness that today not only academics but also practitioners like Mike Pompeo, one of the U.S. top diplomats of the Trump Administration, enjoyed using this resemblance. The major likeness between the old and the new Cold War is the main geopolitical consequence of the great power rivalry: emergence of spheres of influence. Certain empirical observations strengthen this expectation. For example, today nobody is in a position to deny that specific military and diplomatic capacities in the hands of the great powers have been used for the purpose of anti-access/area denial (A2/AD), aiming to prevent the penetration of rival great powers into their own, special area of interest. In particular, Russian and Chinese $\mathrm{A} 2 / \mathrm{AD}$ capabilities seemed to disturb the Trump Administration strongly enough for it to revisit the idea of containing and constraining its rival powers-mainly by strengthening American deterrence capabilities.

Although the Trump Administration's priority for American primacy was crystal clear in the pages of the American National Security Strategy, ${ }^{1}$ Washington's means of deterrence remained rather ambiguous. On the one hand, the U.S. seemed to embrace a 'deterrence by punishment' strategy not only to address Russian and Chinese challenges but also to bring resisting regional powers to their knees. On the other hand, Washington appeared to adopt a kind of 'deterrence by denial' strategy -which meant redesigning the old rimland, ranging from the Pacific to the Atlantic via Southeast Asia, the Af-Pak (Afghanistan and Pakistan), the Gulf, and the Mediterranean. For this new redesign, instead of direct, multifaced, and intensive penetration, less costly and risk-averting means are sought in order to protect the great powers from direct confrontation. Accordingly, we assume that supporting the emergence of regional alliance axes, which are composed of friendly, ambitious, and needy regional players, turned out to be a suitable instrument for the American deterrence by denial strategy.

If we were in the old days of the Cold War, this kind of axis strategy, together with great power rivalry, would require the formation of solid alliances, strong commitments in defense pacts, at least in the form of extended deterrence, and naturally the rejection of hedging as a strategy. However, today's new Cold War is not an ideologically driven, rigid phenomenon, and that is why there 
The entangled rivalry that we observe in the Eastern

Mediterranean is not the exception; it is the direct ramification of this two-layered power struggle among the great and regional powers

is no need to reject the hedging and wedging options available for parties that are coming together in flexible alignments and cooperation schemes with the aim of acquiring benefit. Therefore, the first distinctive characteristic of the new Cold War is its reliance on flexible, shifting, and benefit-oriented alliances. This alliance pattern is not just preferred by great powers, including the U.S., as a cost-effective, more risk-free area-denial strategy in the face of real and potential rivalry, it is also willingly adopted by regional players who have their own distinct national agendas and regional strategic objectives. Contrary to the old days of the Cold War, today's regional players are either too ambitious or too capable to be the proxy or client state of the great powers. They are indisputably bandwagoning parties, but they are not incapable and involuntary followers of the leader. They are rational benefit-seekers, and as such, they can be expected to behave as opportunist -if not revisionist- actors when they spot a window of opportunity. This implies that at the regional level, regional players, too, can be expected to take part in a severe power struggle and a rough rivalry. Therefore, the second distinctive characteristic of the new Cold War is the extension of its alliance pattern. Security competition emerges on the regional and strategic levels with individual features -as a power struggle on the regional level and as a deterrence/constraint game on the strategic level, although these two levels cannot be assumed to be independent from each other. We assume that the entangled rivalry that we observe in the Eastern Mediterranean is not the exception; it is the direct ramification of this two-layered power struggle among the great and regional powers.

\section{Three Axes Strategy: The U.S. Returns to the Eastern Mediterranean Cold War}

In light of this brief theoretical framework, one can easily assume that a new Cold War has already started in the Mediterranean. Indeed, Pompeo was the one declaring that the Mediterranean will be the first front of the great power competition in this regard. First, one can witness the increasing American and Russian military presence there. In the context of Russian-American rivalry, the question of 'who pokes who' is like that of the chicken and the egg. Some argue that Western failure to uphold the post-Cold War European balance has led the Russians to think about the strategic merits of having A2/AD in the Mediterranean. Indeed, Moscow has succeeded in maintaining and even enlarging its $\mathrm{A} 2 / \mathrm{AD}$ bubbles in this region since $2015 .{ }^{2}$ Others argue that Russia's 
upper hand in Western Syria, its military assertiveness in Libya, and diplomatic charm-offensive targeting of regional players like Iran, Turkey, Israel, and Saudi Arabia have convinced the U.S. that it must strike back by bolstering its own strategic posture in the Eastern Mediterranean. Apart from the Russian challenge, China's active investment strategy to have access to, and possibly in the future control, the critical infrastructure of North African states, foremost among them Egypt, coupled with the extension of Beijing's strategic reach to Belt and Road Initiative (BRI) ports in Greece and highway and railway projects targeting a partnership with Turkey and Israel, have accelerated the U.S.'s return to the region. Observing Russian and Chinese access strategy to the region, Washington came to the conclusion that its semi-retrenchment from the MENA region at the end of the Cold War had created a vacuum -that could well be extended to the Persian Gulf- that was being filled by Moscow and Beijing. Despite all these catalyzers, however, the U.S.' return to the Eastern Mediterranean geopolitics has been much delayed.

The U.S. failed to use its unipolar moment after the end of the Cold War to design a structural and institutional framework that could be used by regional players to shape their expectations and constrain their behavior in the Mediterranean realm. Obama underestimated the impact of Syria's devastating civil war, the catastrophic situation that followed NATO's intervention in Libya, and the increase of Russia's capabilities to reach the region on the regional balance of power. However, analysts usually neglect to mention that one of the major strategic mistakes of the Obama Administration was its failure to back its own plan to project an inclusive regional energy cooperation axis including Turkey, the Turkish and Greek Cypriots, Israel, possibly Egypt, and the interested European parties in 2009-2010. Obama's team did succeed in putting together an EastMed Energy Strategy that aimed to build an energy transit connection linking Israel to Europe via Cyprus and Turkey by using gas and money as facilitators of rapprochement among Tel Aviv, North and South Nicosia, and Ankara. Ankara was close to accepting functional cooperation, but Turkey insisted on negotiating a political solution to the Cyprus problem before taking any steps to initiate energy cooperation. As Brenda Schaffer notes, Turkey seemed to believe that pipelines do not bring peace, but peace can facilitate pipelines. ${ }^{3}$ Instead of working with Tel Aviv, North and South Nicosia, and Ankara to find a solution, Washington simply lost interest in the subject and settled for the status quo, which was too weak to resist the factors that led to the breakdown of regional security cooperation after 2011.

Following Russia's direct military penetration into Syria and Libya, however, the U.S. had to return to what was by then an almost overcrowded region. The unipolar moment was skipped over and, consequently, Washington has had to use regional alliances that are based on flexible, benefit-oriented, and shifting alignment logic, to shape the geopolitical design of the region. Two of these 
It is not a surprise that the Libyan turmoil which started after NATO-led intervention has been evolved into a strategic game between different players including European actors and Gulf states alliances were already in existence when Washington decided to use them to contain Russia's influence in the region. One axis is said to be an anti-Turkish realignment based on gas cooperation around Cyprus Island, between Israel, Southern Cyprus, and Greece. ${ }^{4}$ It became crystallized after the EastMed pipeline project was designed as a European Project of Common Interest (PCI) in 2013. For Washington, this gas alliance, which emerged and gradually militarized after the Turkish-Israeli decoupling, is all about constraining both Russia and China by peeling the EastMed states, i.e. Israel, Cyprus, Greece, and Egypt, away from Russian and Chinese reach. Therefore, the first axis which can be called the EastMed gas axis emerged as an alliance for the benefit of the regional states, and an alliance to balance strategic reach of Russia and China for the benefit of the U.S. The EastMed gas axis was coupled with another axis that emerged again in Eastern Mediterranean. This second axis was associated with strategic developments in Libya and not totally independent from gas competition in the region.

The gradual militarization of the EastMed energy alliance is related to several factors, among them the most important one is the Greek Cypriots' desires to instrumentalize the EastMed Pipeline Project and Eastern Mediterranean Gas Forum first to exclude the Northern Cypriots from the energy calculation, then to expand Southern Nicosia's unilateral claims over the maritime jurisdiction zones. The Greek Cypriots grasped these projects as an instrument of marginalization they could operationalize against Turkish and Turkish Cypriot claims. Therefore, they rejected the possibility of cooperation with the Turkish Cypriots and Turkey and declined the proposals of both former TRNC presidents, Derviş Eroğlu and Mustafa Akınc1, for the establishment of a two-community joint energy commission and joint energy searches and drillings. ${ }^{5}$ The Greek and Greek Cypriots' uncooperative stance facilitated the militarization of the energy game. Besides, Greece saw a strategic opportunity in this dispute to turn itself into a European agent of Mediterranean geopolitics. Athens, pressing on various issues ranging from the Kastellorizo (Meis) issue to NAVTEXs (Navigational TEleX), tried to provoke and push Ankara to take certain countermeasures, which in return might open the way to accuse Turkey on Western and European Union (EU) platforms. ${ }^{6}$ Athens thus hopes to compensate for its shortcomings in the face of Turkey's recently achieved naval capacity, which is critical for the balance of power both in the Aegean and the Mediterranean Sea. However, the EastMed energy alliance, which also includes Egypt -a country in need of hot currency but more than that, political 


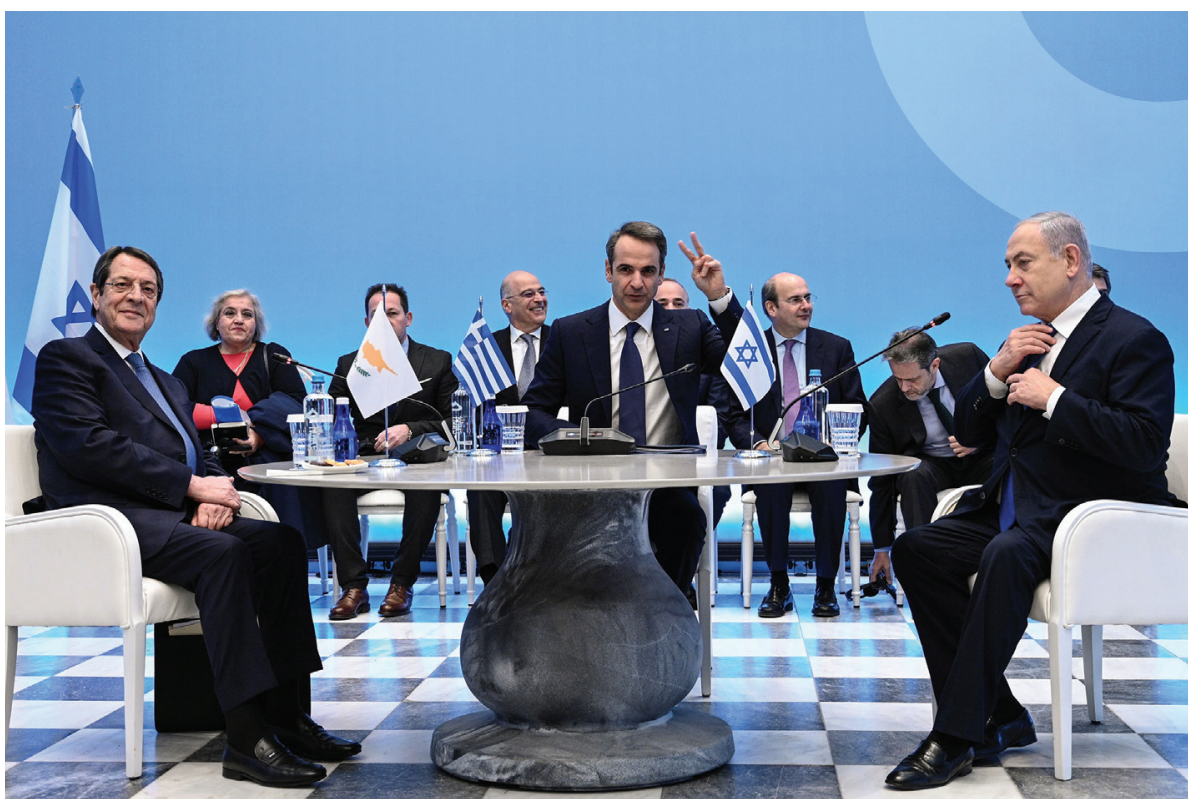

assurances for the security of its regime- was an Israel-centered alignment. Tel Aviv recognized that it would benefit from the concerns and desires of Greece, South Cyprus, and Egypt to pursue its own "littoral control strategy" or "connectivity control strategy" 7 in the region.

We know that despite certain geopolitical changes in the region, the relevant parties have continued to voice their devotion to the EastMed Pipeline Project and the Eastern Mediterranean Gas Forum. Turkey's search and drilling activities continue in the Eastern Mediterranean, so energy security concerns are used as an excuse for practicing "gunboat diplomacy" and increasing defense spending. Greece and Egypt signed an EEZ agreement in August 2020, and joint military exercises have been conducted on an occasional basis. Power projection, such as the participation of Greek and Israeli F-15 and F-16 fighters during exercises, is emblematic of the deterrence purpose of these drills. Scenarios used in the joint drills (whether Greece-Israel, Israel-Cyprus, or, recently, Greece-United Arab Emirates) have been released and have found places in the news; they are argued to be a response to Turkish power projection in the region. ${ }^{8}$ Tel Aviv signed a defense agreement with Athens in 2011 and with South Nicosia in 2012, according to which deployments of the Israeli Air Force and Navy would be hosted at Greek military bases in the Mediterranean; these bases would permit the Israeli Air Force to utilize the airspace and territorial waters around Cyprus to safeguard crucial energy resources. Since the signing of these agreements, Greece, Israel, and the Greek Cypriots have deepened their military cooperation, but still, this triparty military cooperation
(L-R) GASC President Nikos Anastasiadis, Greek PM Kyriakos Mitsotakis and Israeli PM Benjamin Netanyahu, sign an agreement for the EastMed pipeline project, on January 2, 2020.

ARIS MESSINIS / AFP via Getty Images 
seems not to cover binding defense commitments. ${ }^{9}$ Hence it keeps its flexible nature. Some observers, noting this flexibility, postulate a 7+3 Mediterranean Pact that will include Bahrain, Saudi Arabia, and the United Arab Emirates (UAE) along with some European littoral states. ${ }^{10}$ Although anti-Turkish sentiments are being used to legitimize the inclusion of Gulf States to the EastMed axis in these proposals, in reality, a geopolitical linkage between Europe, North Africa/Mediterranean, and the Gulf is a necessity for controlling connectivity (controlling energy or water pipelines, trade flow, human movement, internet, cables, etc.) between the East and the West. Additionally, the militarization of the energy game, as well as the control on the Libyan issue, is all about the struggle to have a share in this connection.

Therefore, it is not a surprise that the Libyan turmoil which started after NATO-led intervention has been evolved into a strategic game between different players including European actors and Gulf states. In the eyes of the U.S., any development aiming to lessen Russian influence in Libya would be welcomed, and that is why Washington seemed first not to reject, then support the strategic alignment of Egypt, Israel, UAE, and France to back Khalifa Haftar after 2013. This Haftarist Libyan axis of alliance -that is also closely related to the stability of Egypt and Cairo and Tel Aviv's anti-Muslim Brotherhood stand- supported Libyan National Army (LNA) forces by flooding money, training, and intelligence. ${ }^{11}$ Interestingly, Turkey emerged as a game-changer in this context by supporting the Government of National Accord (GNA) and by signing and ratifying the Turkey-Libya Maritime Boundaries Delimitation Agreement. Since then, excluding the GNA from the future of Libya has become impossible. In accordance with this changed logic, the already existed Haftarist Libyan axis gained a more anti-Turkish color. Besides, along with that the parties of the first and the second alliance axes provide more maneuvering space and visibility to the UAE in the Eastern Mediterranean, thanks to intelligence-sharing on Libya, the signing of defense cooperation agreements and joint military training, ${ }^{12}$ anti-Iranian rhetoric as a natural extension of the UAE's Iran policy has merged into the anti-Turkish and anti-Russian rhetoric of the already existing alliances between Israel, Greece, and Cyprus on the one hand, and between France, Israel, UAE, and Egypt on the other hand. In this strategic landscape, Trump also found a chance to extend his Administration's anti-Iran policies by giving approval to the presence of Abu Dhabi in the Eastern Mediterranean axes strategy.

Within this framework, the emergence of a third axis of alliance, namely the Abraham Accords alliance was not surprising for anyone. Based on the normalization efforts of Israel and some of the Arab countries, including Bahrain, the UAE, Sudan, and Morocco, the Accords' aim was to roll back Turkey and Iran's rising influence in the Mediterranean. However, since the main architect of the Abraham Accords is the U.S. we can assume that this alliance axis between Israel and some Arab states aims the most important of all to contain 
as much as possible the rising Russian and Chinese influence on the strategic level. It is worth remembering that connectivity in the Eastern Mediterranean, over which Tel Aviv wants to have control, does not merely cover gas pipelines, but also electric and internet cables, water pipelines, and commercial sea transportation from East to West. However, having control over the Eastern Mediterranean connection lines is still waiting for answers to three questions: How this control, if it will be established in the future, will affect Russian A2/AD bubbles? If not China, who will pay money for it? And what will be the reactions of Tehran and Ankara to the 'possibility of Israeli connectivity control' in the Eastern Mediterranean? Answering these questions is not easy. For Israel, having access to the logistic and financial facilities of Arab states of the Abraham Ac-

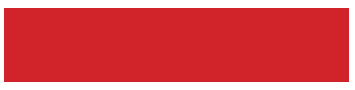

The signing of the Abraham Accords between Israel, Bahrain, the United Arab Emirates, Sudan, and Morocco is now projected as the beginning of a new era for peace in the Middle East cords will be a contributing factor.

Washington's increasing support to the independent but interconnected Israel-centered axes of alliances is much more obvious recently. On the invitation of Athens, Washington established a military base in the Greek Port of Alexandroupolis (Dedeağaç) and modernized the Souda Bay naval base on Crete, where U.S. Secretary of State Mike Pompeo made a speech during his December 2020 visit. In his speech and comments, Pompeo condemned Russian destabilizing activities and denounced Turkish drilling in the region. In a related development, the U.S. Ambassador to Greece, Geoffrey Ross Pyatt, in an interview with Kathimerini, supported Athens' interpretation about the EEZ rights of islands in the Eastern Mediterranean. ${ }^{13}$ The 2019 bipartisan Menendez and Rubio Act, requiring "a comprehensive recalibration of American diplomatic, military and economic policy towards the Eastern Mediterranean and a strong and prosperous alliance between the U.S., Greece, Israel, and Cyprus" turned out to be a real gradually. In September 2020 a Memorandum of Understanding (MoU) was signed between South Nicosia and the U.S. to support the Cyprus Center for Land, Open Seas, and Port Security. Also, the Israel-Greece-Cyprus triparty cooperation and coordination meeting was extended into a four-party meeting to include the U.S. ${ }^{14}$ In the first days of 2021, South Cyprus and the U.S. signed a Declaration of Intent to strengthen their cooperation in the field of border security. ${ }^{15}$ All of these events, together with the role of then-President Trump and his son-in-law, Jared Kushner, as almost the main negotiators of the normalizations between Israel and the Arab states of Abraham Accords, prove that Washington has decided to reshape Mediterranean geopolitics by playing to the desires of some of the regional states, like Israel for having control on the connectivity in the region. 


\section{The Third Axis of Alliance Is Emerging: The Effects of the Abraham Accords}

The signing of the Abraham Accords between Israel, Bahrain, the United Arab Emirates, Sudan, and Morocco is now projected as the beginning of a new era for peace in the Middle East. A wide range of IR analysts have already made numerous comments about the newly inked Abraham Accord that was first agreed to on September 15, 2020, between Israel and the UAE. Later, Bahrain became the second Arab (Gulf) country to accomplish normalization with Israel and, at the time of writing, Sudan and Morocco are the latest states to finalize the Abraham Accord with the Tel-Aviv regime.

Positive expectations abound regarding this new deal that normalizes relations between Israel and some of the Arab states, which others in the Arab world are anticipated to join. Indeed, the normalization deal is said to be bringing about a major shift in Middle Eastern geopolitics, one that marks the end of the Arab states' refusal to engage in peace talks with Israel. The supporters of the deal under the emerging Middle East North Africa (MENA) environment are claiming that three major changes are taking place, as an observable fact, in the Middle East. First, according to advocates of the deal, this leading normalization trend challenges the famous 'No's' that were laid down in the Khartoum Declaration of 1967 -'No' to recognition of, negotiation with, and peace with Israel- rendering them invalid for various Arab countries. ${ }^{16}$

According to supporters of the Abraham Accords, Israel is said to be introducing a new peace deal for the Middle East. However, this deal cannot be portrayed as a peace deal when it is compared with the previous deals of Camp David in 1976 and Jordan in 1994. First, the two Arab (Gulf) states have agreed to ink this normalization deal with Tel-Aviv in acceptance of Israel's declared plan of suspending its annexation of occupied territory in the West Bank. And some EU officials have declared the Abraham Accords as far from meeting the requirements of a comprehensive peace in the Middle East since they do not address the Israeli-Palestinian conflict. According to this viewpoint, unless the Tel-Aviv government agrees to completely abandon its annexation plans and stop settlement construction in the West Bank, this new initiative will remain insufficient. Moreover, this normalization deal was easily sealed because the two Arab (Gulf) states that first signed it had never lived in any conflict with Israel in the past. For the time being, both the UAE and Bahrein seem to deny the three 'No' conditions of the 1967 Khartoum Agreement as well as the condition of the 2002 Arab Peace Initiative that required Tel-Aviv to make concessions to the Palestinians. ${ }^{17}$ So, the Tel-Aviv government currently is favoring a 'peace-to-peace' or 'peace with strength' approach instead of a 'land for peace' approach to the Middle East. 
Second, according to this mindset, Israel's achievement of a normalization agreement with these four Arab states, without the condition of making a compromise on the Palestinian issue, signifies the demise of Palestinian veto power over Israel's ability to bring about pro-Israeli new alignments in the Middle East. Lastly, with the conclusion of the Abraham Accords, Israel is now going through a radical change in its new choice, is swapping the non-Arab states of Turkey, Iran, and Ethiopia -with whom rapprochement was advanced during the times of Israel's Prime Minister David Ben-Gurion and Israeli Diplomat Eliahu Sassoon as a means of providing a buffer against the Arab resistance front- and replacing them with states like the UAE and Bahrein under the Abraham Accords. Hence, Tel-Aviv today seems determined to depart from its previous balance of power strategy -countering of the pan-Arabism - in favor of adopting a new alignment strategy to at most rollback and at least counter regional countries like Turkey and Iran, especially in the Mediterranean basin and beyond. This shift of attention is partly because of Tel Aviv's desire to develop its naval superiority, in terms of which Israel has certain shortcomings, to have control on the connection lines on the and under the nearby seas. Therefore, we can assume that Israel is definitely one of the main benefiters of the Abraham Accords. However, this fact does not change the truth that the Abraham Accords were initiated and negotiated by the Trump Administration.

Indeed, the most striking evaluation of this trend belongs to Ariel Cohen from the Atlantic Council, who described the first Abraham Accord signed between Israel and the UAE as another attempt by Washington to reassert American hegemony in the MENA region. He thinks the U.S. is using this newly developed normalization instrument to try to push back against Chinese and Russian clout in the region. ${ }^{19}$ Hence, at the strategic level, by initiating these deals, from which Israel is also benefited, the U.S. is revisiting its old containment strategy. Returning to containment strategy in the region is an appropriate action for Washington since the impact of great power rivalry has been observed by the U.S. -at least after 2015 .

In addition to trying to rollback Russian and Chinese influence in the Mediterranean basin, Washington's support for the Abraham Accords also aims to solidify the Gulf States' loyalty to the U.S. and to prevent China's penetration into Tel-Aviv's important economic projects. Some of these projects are directly re- 


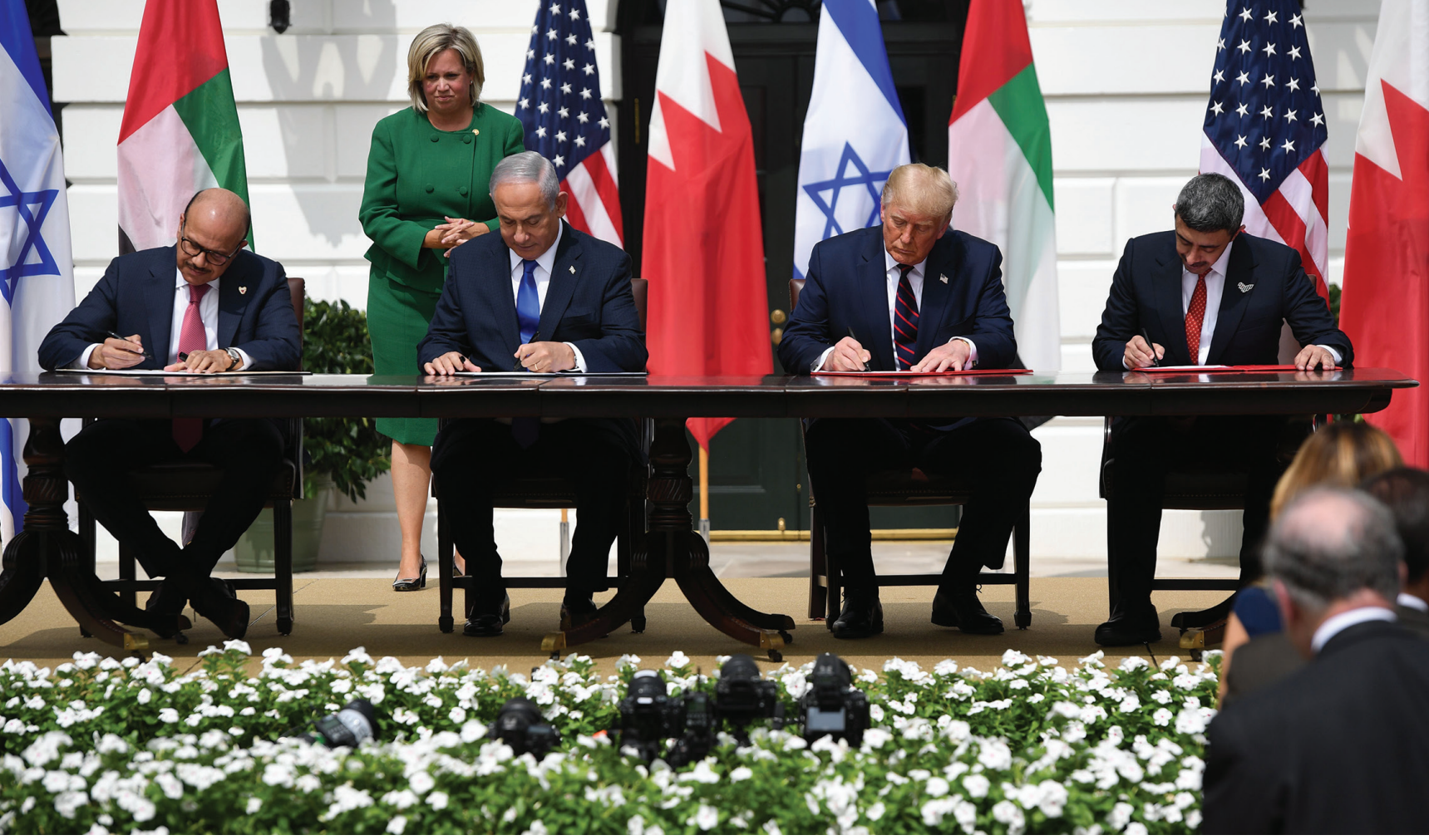

(L-R) Bahrain

Foreign Minister

Abdullatif

al-Zayani, Israeli

PM Benjamin

Netanyahu, U.S.

President Donald

Trump, and UAE

Foreign Minister

Abdullah bin

Zayed al-Nahyan

sign the Abraham

Accords at the

White House in

Washington, D.C.,

September 15 ,

2020.

SAUL LOEB / AFP via

Getty Images

lated to Mediterranean connectivity, like the Euro-Asia Interconnector, which aims to transfer electricity by connecting Israeli grids to Europe via Greece and South Cyprus. It is now certain that after Pompeo's December 2020 visit to Israel, Tel-Aviv has been persuaded to reject China's bid to run the Sorek 2 Desalination Plant in Palmachim. ${ }^{20}$ In this regard, one can easily assert that even Israel has found itself caught between not only Russian-American but also Sino-American competition for global geopolitical influence launched for the control of Mediterranean connectivity.

\section{At the Regional Level: The Abraham Accords Brings More Division and Polarization for the MENA}

The new political, economic and military cooperation between Israel and the four Arab states under the Abraham Accords raises many concerns among various regional actors of the Middle East, such as Turkey, Iran, and Tunisia. Those who are optimistic about the recent normalization deals think that the August 12, 2020 date of the Accord is evidence of the radical change in threat perceptions of Arab (Gulf) countries about the Palestinian issue. ${ }^{21}$ However, strong reactions, at least in terms of rhetoric, are now coming from the rest of the countries of the MENA region that have not become part of the Abraham Accords. These countries criticize the deal as betraying the legitimate rights of the Palestinians. In this complex situation, nobody is certain about what the Abraham Accords will bring to the Middle East in the future. But what is certain -and the immediate impact is observable- is that they have already reinforced the divisions within the Arab world and the Middle East into two, in- 


\section{Ankara's efforts to mediate between the two factions in the İstanbul Meeting have been fruitful, especially after the Israeli-Emirati Deal was signed}

creasingly rivalrous blocks. Hence the Abraham Accords are laying down the seeds of more polarization in the present scene of the fractured Middle East.

The first normalization agreement that was signed between Israel and the UAE aims to solidify Abu Dhabi's involvement not only in Middle Eastern affairs but also in the Eastern Mediterranean. We already know that the UAE has been interested in and associated with the affairs of North Africa via its soft and hard power and has attempted to be influential thereby aligning with the anti-Turkey front within the other axes of alliances in the region. It is true that the practical outcome of this deal will only be seen in years to come, but due to the uneasy relations that have been obtained between Turkey and the UAE for some time, this new U.S.-sponsored, Israeli-based alignment has been met with great suspicion by Ankara. In recent years, relations between Turkey and the UAE have become increasingly strained due to many unfolding incidents. First, Ankara condemned Abu Dhabi for conducting an anti-Turkey political campaign in the Middle East and in the West. As is known, UAE has given active support to the putschist general Haftar in Libya in opposition to the legitimate GNA government that was recognized by the United Nations (UN) in 2015..$^{22}$ In July 2020, news has been confirmed that the UAE air force took part in bombarding Turkey's al-Watiya airbase in Libya. Also, Ankara is very much concerned about Abu Dhabi's close relations with the Fetullah Gülen Terror Organization (FETÖ), and about the UAE's financial and educational support for the PKK and PKK-related terrorist groups in Iraq and in Syria. ${ }^{23}$ Turkey, moreover, has for some time struggled against the attempts to contain it to the Gulf of Antalya, despite Turkey has declared that it has legitimate and legal rights particularly to the West of longitude $32^{\circ} 16^{\prime} 18^{\prime \prime} \mathrm{E}$ as registered to the UN. Abu Dhabi on the other hand has aligned itself with the anti-Turkish Eastern Mediterranean gas alliance. The UAE did not hesitate to send its F-16 fighters to participate in a joint drill with the Hellenic Air Force in August 2020 at a time when the Greek-Turkish border dispute had escalated. ${ }^{24}$ In the eyes of Ankara, this proved its readiness to enter into the Eastern Mediterranean maritime delimitation border dispute -although the UAE is not a littoral state. By signing the Abraham Accords with Israel, the UAE is now hoping to strengthen its foothold in the Mediterranean, North Africa, and even beyond -in Yemen for instance, by the initiation of an Israeli-Southern Transition Council-UAE axis. All in all, Abu Dhabi seems to hope that Israel, due to its shared threat perceptions and benefit expectations across several fronts of MENA, would be 
The possibility of a gradual rapprochement between some states of the alignments and some excluded regional actors, such as Turkey, is frequently mentioned a partner in conducting its policy of empowering various separatist factions in the broader Mediterranean.

However, the Accords are also bringing about the formation of counter-alignments among the rejectionist countries. For instance, the Israeli-Emirati deal has already given way to the revitalization of relations between Hamas and Fatah, via the help of Turkey, making Ankara once again the champion of the Palestinian cause. Ankara's efforts to mediate between the two factions in the Istanbul Meeting have been fruitful, especially after the Israeli-Emirati Deal was signed. ${ }^{25}$ It is not clear how the actors who denounced the agreement, like the Gaza Administration and Iran, will respond. But it is clear that if they feel themselves being pushed into a corner due to the creation of a new front of states around Israel in the Middle East and in the Mediterranean, the negative rhetoric that they adopted against the Accord could turn out to be a real anti-Abraham Accords rapprochement.

\section{Conclusion}

A new Cold War, a new great power rivalry, has arrived in the Eastern Mediterranean. At the strategic level, Chinese economic and Russian military assertiveness has led the U.S. to think twice about its mistakes, which opened a power vacuum in this strategic, geopolitical realm. Washington must find cost-free instruments with which to recraft the structural and institutional design of regional geopolitics, which have become shattered at the regional level because of the harsh power struggle. Until today, the U.S. has seemed to rely on these three Israeli-based, flexible, benefit-oriented axes of alliances. These alignments, however, especially that of the Abraham Accords, are expected to reinforce preexisting divisions in the region unless a radical change occurs. The possibility of a gradual rapprochement between some states of the alignments and some excluded regional actors, such as Turkey, is frequently mentioned. If the conditions of such rapprochement are not operationalized, the IR community expects to see the rise of a counter-Abraham Accords alignment axis in the Mediterranean basin and beyond. This would breed more polarization and would be counterproductive to the aim of stabilizing the region. It could also generate more costs and increase the risk of confrontation for the great powers, including the U.S. while reducing regional powers' freedom of action.

Hence, the IR community, both at the regional and strategic level, should give attention to Turkey's diplomatic calls to convene a Mediterranean Conference 
where the main disputes among the littoral states of the Mediterranean could be resolved in an equitable way in accordance with International Law. In this way, oriented toward a win-win mindset rather than the prevailing zero-sum mindset in the Mediterranean basin, the people of MENA could benefit from the evolution of gradually expanding pockets of inclusive environments in the Mediterranean. One may hope that the al-Ula Declaration, and the new rapprochement between Qatar and the other five states of the Gulf Cooperation Council, will trigger and motivate a reconciliation spillover to the Mediterranean and bring an end to the rift among regional powers that was exploited by the Trump Administration.

\section{Endnotes}

1. "National Security Strategy of the United States of America," The White House, (December 2017), retrieved from https://www.whitehouse.gov/wp-content/uploads/2017/12/NSS-Final-12-18-2017-0905. pdf.

2. Nurşin Güney and Vişne Korkmaz, "New Russian Mahanism Failed: Futile Geopolitical Dreams in the Black Sea and the Mediterranean," in Nurşin Güney (ed.), The New Geopolitical Realities for Russia, (London: Lexington Publishers, 2019), pp. 7-30.

3. Brenda Schaffer, "Can New Energy Supplies Bring Peace?" GMF, (May 11, 2014), retrieved from https:// www.gmfus.org/publications/can-new-energy-supplies-bring-peace.

4. Mehmet A. Kancl, "Analysis: To Encircle Turkey with an Energy Project: Transformation of EastMed," Anadolu Agency, (September 10, 2020), retrieved from https://www.aa.com.tr/en/analysis/analysis-toencircle-turkey-with-an-energy-project-transformation-of-east-med/1968544.

5. Kayhan Karaca, "Hidrokarbon Adası Kıbrıs," DW, (November 24, 2014), retrieved from https://www.dw. com/tr/hidrokarbon-adas\%C4\%B1-k\%C4\%B1br\%C4\%B1s/a-18082205; Muhammet Ikbal Arslan, "Akıncı'dan Hidrokarbon Önerisini Reddeden Rumlara Yanıt," Anadolu Agency, (July 16, 2019), retrieved from https://www.aa.com.tr/tr/dunya/akincidan-hidrokarbon-onerisini-reddeden-rumlara-yanit/1533418.

6. Muhittin Ataman, "Greece Benefits from Rising Tensions with Turkey," Daily Sabah, (August 5, 2020), retrieved from https://www.setav.org/en/greece-benefits-from-rising-tensions-with-turkey/; Tevfik Durul, "Yunanistan Başbakanı Miçotakis: Türk-Yunan Anlaşmazlığını, Türkiye-AB Anlaşmazlığına Çevirmeyi Başardık," Anadolu Agency, (December 7, 2020), retrieved from https://www.aa.com.tr/tr/dunya/yunanistan-basbakani-micotakis-turk-yunan-anlasmazligini-turkiye-ab-anlasmazligina-cevirmeyi-basar$\operatorname{dik} / 2068836$.

7. Chris Parry, "The Eastern Mediterranean: A Brief Geo-Political Overview," in J. Stöht and S. Bruns (eds.), Maritime Security in the Eastern Mediterranean, (Baden-Baden: Nomos, 2018), pp. 19-28; Yael Teff-Seker, Aviad Rubin, and Ehud Eiran, "Israel's 'Turn to the Sea' and Its Effect on Israeli Regional Policy," Israel Affairs, Vol. 25, No. 2 (2019), pp. 234-255.

8. Gabe Fisher, "Joint Israli- Greek Military Drill Seen by Some as Rebuff to Turkey", The Times of Israel, (April 1, 2012) retrieved from https://www.timesofisrael.com/israel-greek-us-military-run-joint-exercises-in-eastern-med/; Nick Kampouris, "Five-Nation Military Exercise in the East Mediterranean Sends Message to Ankara," Greek Reporter, (November 29, 2020) retrieved from https://greekreporter. com/2020/11/29/five-nation-military-exercise-in-east-mediterranean-sends-message-to-ankara/.

9. "Israel, Greece and Cyprus Agree to Boost Defense Cooperation," The Times of Israel, (November 13, 2020), retrieved from https://www.timesofisrael.com/israel-greece-and-cyprus-agree-to-boost-defense-cooperation/.

10. Rauf Baker, "7+3: Greece as Part of Mediterranean Bloc," BESA Perspective Papers, (October 1, 2020), retrieved from https://besacenter.org/perspectives-papers/greece-mediterranean-bloc/. 
11. Yosi Melman, "Israel's Little-known Support for Haftar's War in Libya," Middle East Eye, (April 15, 2020), retrieved from https://www.middleeasteye.net/news/israel-little-known-support-haftar-war-libya.

12. Sean Methews, "UAE Joins Greek, Egyptian Naval Exercise in Eastern Mediterranean," Al Monitor, (December 2, 2020), retrieved from https://www.al-monitor.com/pulse/originals/2020/12/uae-greecedefense-agreement-turkey-eastern-mediterranean.html.

13. "Ambassador Pyatt's Interview to Kathimerini," U.S. Embassy and Consulate in Greece, (June 7, 2020), retrieved from https://gr.usembassy.gov/ambassador-pyatts-interview-to-kathimerini/.

14. "Greece, Israel, US, Cyprus to Boost Energy Cooperation," Reuters, (August 7, 2019), retrieved from https://www.reuters.com/article/us-greece-energy-eastmed/greece-israel-u-s-cyprus-to-boostenergy-cooperation- idUSKCN1UX1EP.

15. "Cyprus and the US Border Security," Greek City Times, (January 6, 2021), retrieved from https://greekcitytimes.com/2021/01/06/cyprus-and-the-us-border-security/.

16. Norlen Sinai, "Abraham Accords," George Marshal European Security Studies, No. 64 (October 20, 2020), retrieved from https://www.marshallcenter.org/sites/default/files/files/2020-10/Security\%20lnsights\%2064\%20-\%20Norlen\%20SInai\%20-\%20The\%20Abraham\%20Accords\%20-\%200CT\%202020. pdf.

17. Yossi Alpher, "Israeli Regional Strategies: Balancing the Arab Core, the New Periphery, and Great Powers," IE Mediterranean Year Book, (2017), retrieved from https://www.iemed.org/observatori/areesdanalisi/arxius-adjunts/anuari/med.2017/IEMed_MedYearbook2017_israeli_regional_strategies_ Alpher.pdf/.

18. Leon Hadar, "The Middle East Channel: The Collapse of Israel's 'Periphery Doctrine,"' Foreign Policy, (June 26, 2010), retrieved from https://foreignpolicy.com/2010/06/26/the-collapse-of-israels-periphery-doctrine/.

19. Giorgi Cafiero and Daniel Wagner, "China and the Abraham Accords Peace Agreement," Middle East Peace Institute, (September 22, 2020), retrieved from https://www.mei.edu/publications/china-andabraham-accords-peace-agreement.

20. Yoram Gabison, "Amid US Pressure Chinese Firm Losses Contract to Build Israeli Plant," Haaretz, (May 26, 2020), retrieved from https://www.haaretz.com/israel-news/.premium-amid-u-s-pressure-chinesefirm-losses-contract-to-build-israeli-plant-1.8873032.

21. Zoltan Egeresi, "How the Abraham Accords Affected Turkish Foreign Policy," The Moshe Dayan Center for the Middle Eastern and African Studies, (October 15, 2020), retrieved from https://dayan.org/content/ how-abraham-accords-affected-turkish-foreign-policy\#_edn6.

22. Egeresi, "How the Abraham Accords Affected Turkish Foreign Policy;" Jonathan Felton Harvey, "What Do the Abraham Accords Entail for the Middle East and North Africa?" Anadolu Agency, (August 22, 2020), retrieved from https://www.aa.com.tr/en/analysis/analysis-what-do-the-abraham-accords-entail-for-the-middle-east-and-north-africa/1981633.

23. Egerisi, "How the Abraham Accords Affected Turkish Foreign Policy."

24. Egerisi, "How the Abraham Accords Affected Turkish Foreign Policy."

25. Egerisi, "How the Abraham Accords Affected Turkish Foreign Policy." 